\title{
The Lichtenstein Plug Technique: The Safe Repair
} \author{
Danta Fundora ${ }^{4}$, Eduardo Garcia Castillo ${ }^{4}$ and Lais Angèlica Ceruto Ortiz ${ }^{5}$ \\ ${ }^{2}$ Consultant Professor in general surgery, Cuba \\ ${ }^{3}$ Specialist of I Degree in general surgery Auxiliary Professor and Auxiliary Researcher, Cuba \\ ${ }^{4}$ Specialist of I Degree in general surgery Assistant Professor, Cuba \\ ${ }^{5}$ Second year resident in general surgery, Cuba \\ *Corresponding author: Pedro Rolando López Rodríguez, National Hospital, Havana, Cuba
}

Pedro López Rodríguez ${ }^{*}$, Pablo G Pol Herrera² ${ }^{2}$ Jorge Satorre Rocha ${ }^{3}$, $0 l g a$ León González ${ }^{3}$, Luis Manuel

${ }^{1}$ Specialist of I Degree and II Degree in general surgery, Axiliary Professor, Consulting Professor and Auxiliary Researcher, Cuba

\section{ARTICLE INFO \\ Received: 幽 October 30, 2019 \\ Published: 慧 November 12, 2019}

Citation: Pedro López Rodríguez, Pablo G Pol Herrera, Jorge Satorre Rocha, Olga León González, Luis Manuel Danta Fundora, et al. The Lichtenstein Plug Technique: The Safe Repair. Biomed J Sci \& Tech Res 22(5)2019. BJSTR. MS.ID.003800.

\section{ABSTRACT}

Summary: Various techniques have been developed for the repair of femoral hernia. The technique with the Lichtenstein Plug since 1989 has allowed to obtain a lower rate of complications and recurrences, as well as an early recovery of the patient's usual activities. Its application, widely spread in elective surgery, can also be performed in emergency surgery. The aim of this work is to review the experience of our basic group of work in the surgical treatment of femoral hernia using this technique.

Methods: A retrospective descriptive observational study was conducted in our basic work group from the surgery service of the General Teaching Hospital "Enrique Cabrera" between 2009 and 2018, to which this surgical technique was applied. We study the anatomical variants of hernias as well as post-operative complications and clinical evolution.

Results: The mean age of the patients was 58.7 years (19-92 years), being the female with the highest incidence $78 \%$, as well as, the most frequent location the right, $67.5 \%$. The prosthesis used in the hernioplasty was that of polypropylene. Local anesthesia was applied to 29 patients (63\%) of them. The average surgical time was25 minutes, (15-65 minutes). Ambulation was early and the average hospital stay was lessthan 24 hours, in most patients. Only one infection of the wound and one hernia recurrence in one patient was confirmed.

Conclusion: Therefore, we believe that the Lichtenstein Plug technique should be considered among the techniques of choice in the treatment of femoral hernia

\section{Introduction}

Many technical procedures have been developed to repair femoral hernia. Since 1989 the Lichtenstein Plug technique has diminished the post-operative complication and recurrence. The advantages present, in term of pain and post-operative discomfort, recovery of physical and labor activity is very good. This technique can be indicated in complicated hernia [1,2]. The aim of this article is to describe the surgical technique and to analyze the preliminary results of our series of 46 patients.

\section{Methods}

We performed a descriptive and observational study with a retrospective Character in our surgical group at "Dr. Enrique Cabrera" Teaching and General Hospital, between the years 20092018 to the patients who underwent surgical repair of femoral hernia through the Lichtenstein Plug technique and their postoperative behavior. The following variable were analyzed: age, type 
of hernia, tolerance to local anesthesia, surgical technique, operating time, post-operative pain, wound sepsis and recurrence of hernia; return to activity. All these ítems were collected in Microsoft Excel base and later were processed in the SPSS statistics program.

\section{Results}

Table 1 shows the most relevant results of this series. We can see that the largest number of patients was women, 36 in total, $78 \%$ and there were only 10 men, 22\%; which is in accordance with what has been reported with other authors. The most frequent location was the right one in 31 patients, $67.5 \%$ and the average age of the patients was 58, 7 years, with a range between 19 and 92 years [3]. 47 surgical interventions were performed in 46 patients, since there was a relapse, $2.2 \%$. It was a patient who had undergone surgery for a recurrent, incarcerated femoral hernia and who had a wound infection in the postoperative period [4]. The most used anesthesia was the local one, which was applied to 29 patients. $63 \%$, followed by the regional one in 12 patients, $26.2 \%$ of the cases, Table 2. It is also observed in this table that the average duration of surgical interventions was 25 minutes and the hospital stay was 8 hours, like other authors [5-7].

Table 1: Sex, Location, Recurrence, Varity, Middle Ages.

\begin{tabular}{|c|c|c|c|}
\hline & $\begin{array}{c}\text { Number of } \\
\text { Patients }\end{array}$ & Percentage \% & Chl \\
\hline Men & 10 & 22,0 & $0.08 \pm 0.01$ \\
\hline Women & 16 & 78,0 & $0.08 \pm 0.01$ \\
\hline Rigth & 31 & 67,5 & $0.19 \pm 0.01$ \\
\hline Letf & 15 & 32,5 & $0,17 \pm 0.01$ \\
\hline Recidiva & 1 & 2,2 & \\
\hline Primary & 45 & 97,8 & \\
\hline Middle Ages & 58,7 years & (Range 19-92) & \\
\hline
\end{tabular}

Source: Data collection form.

Table 2: Type of Anesthesia, Average Duration, Hospital media stay.

\begin{tabular}{|c|c|c|}
\hline Type of Anesthesia & Number of Patients & Porcentage \% \\
\hline Local & 29 & 63,0 \\
\hline Regional & 12 & 26,2 \\
\hline General & 5 & 10,8 \\
\hline Average Duration & 25 Minutes & (Ranger 15-65) \\
\hline Hospital Media Stay & 8 Horas & (Ranger 6-48) \\
\hline 45 & 97,8 & \\
\hline 58,7 years & (Range 19-92) & \\
\hline
\end{tabular}

Source: Data collection form.

The only recurrences observed in our series were in a patient who was operated on because of a relapsed, incarcerated hernia. In the surgical act a wide femoral orifice was observed that was occluded with a cylinder of polypropylene mesh like all the other patients. In the postoperative period he presented wound infection and recurrence at four months. In the reoperation, it was found that the cylindrical prosthesis was of insufficient size to occlude the femoral orifice. This patient underwent a pre-peritoneal repair with a wide patch of polypropylene mesh.

\section{Discussion}

The great advantage of this technique is the absence of tension, and for this the mesh must completely occlude the hernia lorifice. Therefore, the prosthesis will be adapted to the size of the hole and not the reverse, avoiding the partial closure of the hole when it is large, since this would give rise to tension zones with the consequent risks of recurrence. In the primary femoral hernia (Figure 1), the hernial orificeis small (Figure 2) and can be satisfactorily occluded with the polypropylenecy lindrical prosthesis (Figure 3). The low rate of complications and its simple and rapid execution Means that we consider it as a technique of choice in cases of primary femoral hernia. In recurrent femoral hernia, the ring is generally larger, and in cases of urgent surgery due to a stuck or strangulated femoral hernia, it is often necessary to expand the hernia ring to adequately manage the affected bowel. In no case should try to reduce the size of the hole by suture, even large, because of the danger of recurrence. In these cases, it may be useful to replace the Lichtenstein cylindrical prosthesis with a cone-shaped mesh as it has been used by other authors. The prosthetic material used in the cases has been a monofilament polypropylene mesh, as it is considered the most appropriate, since it is strong, resistant to infection and the cases of intolerance are practically non-existent since the yellow a rapid interstitial fibroblastic proliferation that fixes it intimately to the tissues, which fixes it intimately to the tissues, according to reports Mansilla Molina D et al. [8].

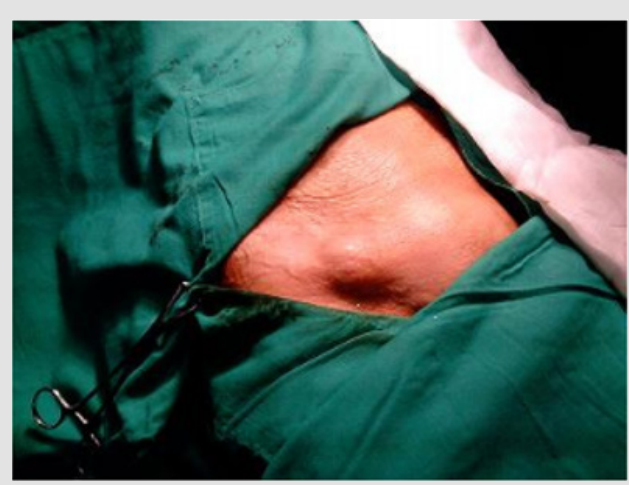

Figure 1: Patients with right femoral hernia.

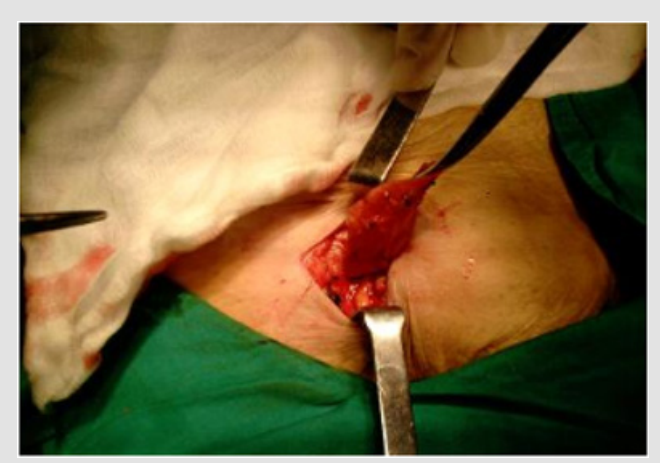

Figure 2: Hernia sac dissected through the dilated femoral orifice. 


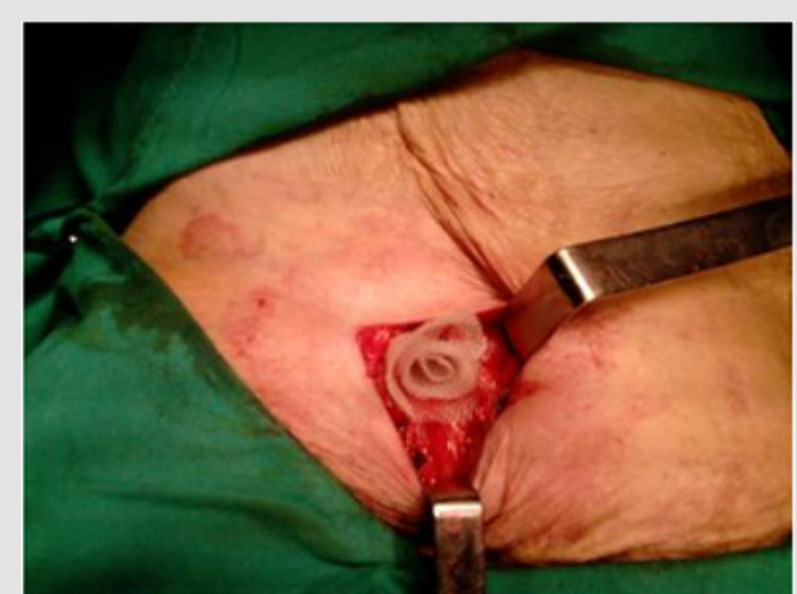

Figure 3: Occlusion of the femoral ring with a polypropylene cylindrical prosthesis.

In our series, we did not have any deaths and the highest morbidity occurred in the group of older patients. For this reason, to get her with the high probability of strangulation of the femoral hernia, [9] we believe that all patients diagnosed with femoral hernia, regardless of age and surgical risk, should undergo a programmed procedure after adequate preparation, thus avoiding situations adverse events that increase morbidity and mortality, according to what was expressed by Porrero JL in 1993 and Chamary V.L. also in 1993 [10-12]. Local anesthesia was the most used in our series, $63 \%$, due to the great benefits they bring to the patients with high surgical risk, however, at present the most frequently used is the regional one $[13,14]$. Finally, we can affirm that the series we present is not very extensive, but it is supported by good results, both in the immediate post-operative period and in there incorporation of the patients to his habitual activity, as well as, in the absence of recurrences or complications delayed, when applying the Lichtenstein Plug technique in the repair of the femoral hernia. We can conclude affirming like other authors [1416]. Which are equally significant, the convenience of repair when performed under local anesthesia, which is ideal if it is scheduled surgery, since the reduction of tissues trauma and post-operative discomfort and a lower incidence of sepsis and tissues tension, reduce potential recurrence and favor early Ambulation [17-19].

\section{Conclusion}

For all of the above, we believe that the Lichtenstein Plug technique should be of choice in the surgical treatment of femoral hernia.

\section{Conflicts of Interest}

The authors do not declare having conflicts of interés.

\section{References}

1. Lichtenstein IL, Shore JM (1974) Simplified repair of femoral and recurrent inguinal hernias by a "plug" technic. Am J Surg 128(3): 439444 .

2. Nicholson S, Keane TE, Devlin HB (1990) Femoral hernia: An avoidable source of surgical mortality. Br J Surg 77(3): 307-308.

3. Bendavid R (1989) New techniques in hernia repair. World J Surg 13(5): 522-531.

4. Lichtenstein IL (1987) Herniorrhaphy. A personal experience with 6,321 cases. Am J Surg 153(6): 553-559.

5. Gilbert AI (1992) Sutureless repair of inguinal hernia. Am J Surg 163(3): 331-334.

6. Robbins AW, Rutkow IM (1998) Mesh plug repair and groin hernia surgery. Surg Clin North Am 78(6): 1007-1023.

7. Lichtenstein IL, Shulman AG, Amid PK (1990) Use of mesh to prevent recurrence of hernias. Postgrad Med 87(1): 155-158.

8. Mansilla Molina D, Perez Folques JE, Civera Muñoz J, Vazquez Ruiz J, Polo Perez MI, et al. (1999) Hernioplasty without tension in crural hernias. Cir Esp 65: 176-178.

9. Cobaleda FSB, Muñoz-Najar AG, Trujillo BM, Borajo MC, Matas FA, et al. (2000) Recurrent inguinal hernia: treatment using a preperitoneal approach and a wide polypropylene mesh prosthesis. Cir Esp 67: 354357.

10. Porrero JL, Ten M, Martín D, Lomar M (1993) Experience with the LUG tenstein PLUG technique in the treatment of Crural Hernia. Cir Esp 53: 97-99.

11. Chamary VL (1993) Femoral hernia: Intestinal obstruction is an unrecognized source of morbidity and mortality. Br J Sur 80(2): 230232.

12. Porrero JL, Sánchez-Cabezudo C, Bonachía O, López-Buenadicha A, Sanjuánbenito A, et al. (2005) Inguinofemoral hernia: multicenter study of surgical techniques. Cir Esp 78(1): 45-49.

13. Rafael RF, Fernandez EIM, Rabassa PPC, Curbelo ONM, Weinman ESE (2003) Use of bioprothesis in complicated inguinocrural hernias. Cuban Rev Cir 42: 1-7.

14. de Juan A, Mena A, Die J, Rodríguez G, Sanjuanbenito A, et al. (2003) Is the Lichtenstein Plug technique suitable for the treatment of complicated crural hernia? Spanish Surgery 74(2): 104-107.

15. Acevedo A, Reyes E, Herrera JC (2005) Femoral hernia: Study of the posterior wall of the Inguinal Canal. Reuchi Cir 57: 495-499.

16. Townsend CM, Beauchamp RD, Evers BM, Mattox KL (2007) Sabiston textbook of Surgery. 18th ed. Saunders Elservier, USA.

17. Lòpez Rodriguez PR, Leòn Gonzàlez OC, Satorre Rocha J, Pol Herrera P, Garcia Castillo E (2012) Femoral Hernia. Ten years of experience in using the Lichtenstein Plug Technique. Rev Cuban Cir 51: 211-216.

18. Townsend CM, Beanchamp RD, Evers BM, Mattox KL (2017) Sabiston Texbook of Surgery. 20th ed. Elsevier Saunders, USA.

19. Lockhart K, Dunn D, Teo S, Ng Jy, Dhillon M, et al. (2018) Mesh versus non-mesh for inguinal and femoral hernia repair. Cochrane Database Syst Rev 9: CD 011517. 
ISSN: 2574-1241

DOI: 10.26717/BJSTR.2019.22.003800

Pedro López Rodríguez. Biomed J Sci \& Tech Res

(c) (i) This work is licensed under Creative

Submission Link: https://biomedres.us/submit-manuscript.php

$\begin{array}{ll}\text { BIOMEDICAL } & \text { Assets of Publishing with us } \\ \text { RESEARCHES } & \text { - Global archiving of articles } \\ & \text { - Immediate, unrestricted online access } \\ & \text { - Rigorous Peer Review Process } \\ \end{array}$

